\title{
EFFECT OF THE PROCESSING ON SOME CHEMICAL COMPONENTS OF PINEAPPLE TROPICAL JUICE
}

\section{EFEITO DO PROCESSAMENTO EM ALGUNS COMPONENTES QUÍMICOS DO SUCO DE ABACAXI TROPICAL}

\author{
GERALDO A. MAIA ${ }^{1}$ \\ ALINE G. FERNANDES ${ }^{2}$ \\ GERUSA M. SANTOS 3 \\ DANIELE S. SILVA \\ PAULO H. M. DE SOUSA ${ }^{5}$ \\ ISABELLA M. BRASIL ${ }^{6}$ \\ ANA V. V. FONSECA ${ }^{7}$
}

The chemical and physicochemical changes during the tropical pineapple juice processing were evaluated. It was verified that all the chemical and physicochemical parameters evaluated showed a statistical difference at a level of $5 \%$ of probability by the Tukey test, exception for carotenoid content. Total titratable acidity, reducing sugar and carotenoid content increased during the processing. The $\mathrm{pH}$, total soluble solids (Brix), total sugars and anthocyanins content did not differed statistically among formulation/homogenation and after thermal treatment phases. The results suggested that processing phases such as extraction, formulation/homogenation and thermal treatment had a significant effect on the chemical and physicochemical characteristics of the tropical pineapple juice.

Keywords: Pineapple juice, hot fill processing, industrial processing

\section{RESUMO}

Alterações químicas e físico-químicas durante o processamento de suco tropical de abacaxi foram avaliadas. Verificou-se que todos os parâmetros químicos e físicoquímicos avaliados apresentaram conteúdo de carotenóides. Acidez total titulável, açúcar redutor e conteúdo de carotenóide aumentaram durante o processamento. $\mathrm{O} \mathrm{pH}$, sólidos solúveis totais ( $\left.{ }^{\circ} B r i x\right)$, açúcares totais e conteúdo de antocianinas não apresentaram diferença estatística entre as fases de tratamento formulação/homogeneização e tratamento térmico. Os resultados sugerem que as fases do processamento como

\footnotetext{
${ }^{1}$ Doutor em Ciências de Alimentos, Universidade Federal do Ceará, UFC, Ceará, e-mail: gmaia@secret.com.br.

${ }^{2}$ Mestre Tecnologia de Alimentos, Universidade Federal do Ceará, UFC, Ceará.

${ }^{3}$ Mestranda Tecnologia de Alimentos, Universidade Federal do Ceará, UFC, Ceará

${ }^{4}$ Mestre Tecnologia de Alimentos, Universidade Federal do Ceará, UFC, Ceará.

${ }^{5}$ Doutor em Ciência e Tecnologia de Alimentos, Universidade Federal de Viçosa, Viçosa, MG.

${ }^{6}$ Doutora em Bioquímica, Universidade Federal do Ceará, UFC, Ceará.

${ }^{7}$ Graduada em Engenharia de Alimentos, Universidade Federal do Ceará, UFC, Ceará.
} 
extração, formulação/homogeneização e tratamento térmico tiveram efeito significativo nas características químicas e físico-químicas do suco tropical de abacaxi.

Palavras-chave: Suco tropical de abacaxi, processo hot fill, processamento industrial

\section{INTRODUCTION}

Brazil is currently the third largest fruit producer in the world. It loses only to China and India (ABDI, 2006). Fruit juices world market is about US $\$ 5.0$ billions year ${ }^{-1}$, in which Brazil is responsible for $33 \%$. Brazil is the greatest world exporter of orange juice, it exports $50 \%$ of the total world orange juice, besides of passion fruit, pineapple, banana and acerola products (ANBA, 2006).

Pineapple is an important tropical fruit (BARTHOLOMEW et al., 2002), particularly in the form of processed products. In the nontropical countries the juice of tropical fruits, such as the pineapple is considered exotic (BIOTIMES, 2002). Being considered a fruit symbol of the tropics, the pineapple is being appreciated all over the world due to its very pleasant aroma and flavor (TODA FRUTA, 2005). It is also the most important tropical fruit concerning to processed volume. This fruit has a low vitamin C content (10 to 25 $\mathrm{mg}$ of ascorbic acid per $100 \mathrm{~g}$ of fruit), however it shows a larger sensory acceptance on the consumer's taste. The nutritious value of the pineapple is summarized practically to its energy value, due to its sugars content (MATSUURA \& ROLIM, 2002).

Considering the expansion of the Brazilian pineapple production in addition to the exportation income it is necessary studies that aimed the preservation of this fruit. Researches concerning the effects of the processing on the components of tropical fruit juices are scarce. Frequently, only the losses of vitamin $C$ are evaluated (GIMENEZ et al., 2002; GAHLER et al., 2003; LIMA et al., 2001). The purpose of this research was to study the influence of the processing variables on the chemical and physicochemical changes of the pineapple tropical fruit juice.

\section{MATERIALS AND METHODS}

Pineapple fruits (Ananas comosus $\mathrm{L}$, Merril) fresh, healthy and mature, bought from Fortaleza metropolitan region producers, at the state of Ceará, Brazil, latitude 03.45S, longitude $38.35 \mathrm{~W}$, and average altitude $16.50 \mathrm{~m}$. Samples were quickly transported on plastic bags to a local fruit juice processing industry.

\section{Preparation of tropical pineapple juice}

A flow diagram of the process is showed in Figure 1. Fresh pineapples had the crown removed followed by washing. The fruits were cut longitudinally and passed trough the extraction machine where the inedible portions were separated apart from the juice. The raw juice was extracted through a mesh pulping machine (0.8 mesh). After pulping the juice was formulated using 500 ppm sodium benzoate, 200 ppm sodium metabissulfite and citric acid to standardize the acidity. The prepared juice was then homogenized using a pressure valve homogenizer (100 atm) and deaerated through a vacuum deaerator $(600 \mathrm{mmHg})$ kept at $50^{\circ} \mathrm{C}$, following heat treatment in a tubular pasteurizator machine at $90^{\circ} \mathrm{C}^{6} 6 \mathrm{~s}^{-1}$, and conveyed to the filler to fill hotly $\left(85^{\circ} \mathrm{C}\right)$ in glasses bottles of $500 \mathrm{ml}$ capacity closed immediately and subsequently allowed to cool, labeled and stored at room temperature $\left(28 \pm 2^{\circ} \mathrm{C}\right)$. 


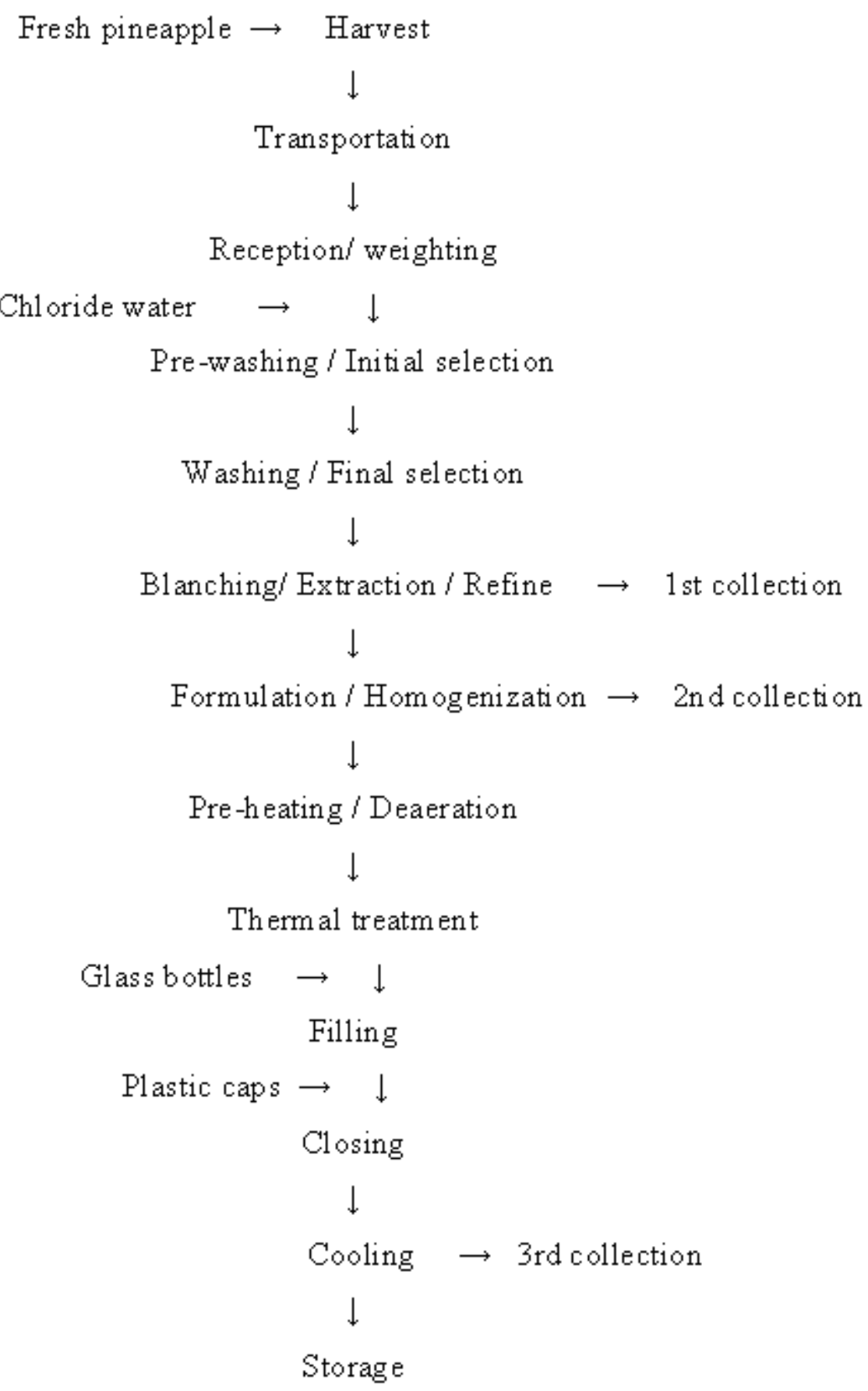

Figure 1. Flow scheme for the production of tropical pineapple juice bottled by hot fill process (Adapted from MAIA, 2000).

\section{Analytical methods}

Samples were collected and stored at - $20{ }^{\circ} \mathrm{C}$ after the following processing phases: extraction, formulation/ homogenization and thermal treatment for future analyses. The following determinations were carried out: $\mathrm{pH}$ with a Hanna Instruments ${ }^{\circledR} \mathrm{HI}$ level $9321 \mathrm{pH}$ meter (United Kingdom). Total titratable acidity was determined according to the method outlined by BRASIL (2005) and expressed as " $g$ citric acid $100 \mathrm{ml}$ juice ${ }^{-1}$ "; Brix was measured at $20{ }^{\circ} \mathrm{C}$ using an automatic Atago ${ }^{\circledR}$ PR-101 digital refractometer (Atago, Tokyo, Japan); vitamin $C$ by COX \& PEARSON method (1976); total and reducing sugars according to MILLER (1959); carotenoid content (HIGBY, 1962); total anthocyanins (FRANCIS, 1982) and color changes by 
RANGANA methodology (1997) by measuring the transmittance using a spectrocolorimeter through O.D measurements at $440 \mathrm{~nm}$.

\section{Data analysis}

The results were reported as an average of three replicates. The model of Analysis of variance (ANOVA) was the delineation entirely randomized, with three repetitions of the experiments. The Tukey test was applied to the different sets of data with a significant level of 0.05 (á=0.05) using the Statistical Analyses System (SAS) version 9.1 (SAS, 2006).

\section{RESULTS AND DISCUSSION}

Table 1 shows the mean value of the chemical and physicochemical analyses results obtained from different operations of tropical pineapple juice processing. It was observed a significance difference between the extraction and formulation/homogenation operations at a level of $5 \%$ of probability in all the parameters studied, with the exception in total and reducing sugars and total carotenoids content. This difference could be associated to the dilution that the juice suffered during the formulation process.

Table 1. Compositional and physicochemical analyses obtained from different phases of tropical pineapple juice

\begin{tabular}{lccc}
\hline Processing phases* & Extration & $\begin{array}{c}\text { Formulation/ } \\
\text { Homogenenation }\end{array}$ & $\begin{array}{c}\text { After Thermal } \\
\text { treatment }\end{array}$ \\
\hline pH & $3.78 \mathrm{a}$ & $3.76 \mathrm{~b}$ & $3.76 \mathrm{~b}$ \\
SST ('Brix) & $11.67 \mathrm{a}$ & $11.07 \mathrm{~b}$ & $10.97 \mathrm{~b}$ \\
ATT (mg citric acid /100g) & $0.67 \mathrm{~b}$ & $0.62 \mathrm{c}$ & $0.72 \mathrm{a}$ \\
Total sugars (\%) & $9.65 \mathrm{a}$ & $9.48 \mathrm{ab}$ & $8.46 \mathrm{~b}$ \\
Reducing sugars (\% de glicose) & $5.37 \mathrm{~b}$ & $5.36 \mathrm{~b}$ & $7.02 \mathrm{a}$ \\
Color (Abs) & $0.19 \mathrm{a}$ & $0.16 \mathrm{~b}$ & $0.14 \mathrm{c}$ \\
Vitamin C (mg/100g) & $33.68 \mathrm{a}$ & $31.23 \mathrm{a}$ & $22.21 \mathrm{~b}$ \\
Anthocyanins (mg/100g) & $0.62 \mathrm{a}$ & $0.49 \mathrm{ab}$ & $0.22 \mathrm{~b}$ \\
Carotenoids (mg/100g) & $0.15 \mathrm{a}$ & $0.15 \mathrm{a}$ & $0.21 \mathrm{a}$ \\
\hline
\end{tabular}

Average of three determinations. Different letters means statistical significance range (á=0.05); Abreviations: SST:Total soluble solids; ATT: Total treatable acidity;

Pineapple juice $\mathrm{pH}$ is also known to vary with growing location, harvest time, fruit maturity and other similar factors which affect the fruit (HODGSON \& HODGSON, 1993). The $\mathrm{pH}$ of pineapple tropical juice slightly diminishes due to the addition of citric acid during the formulation/homogenation phase, causing the increase in the acidity. Our data are according to the values found by MATSUURA \& ROLIM, (2002) working with pasteurized pineapple juice.

The variation of the total soluble solids content during the tropical pineapple juice processing shows a typical behaviour for this kind of process. The dilution decreased the total soluble solids content, as expected.
This decrease of total soluble solids is also associated to the non enzymatic reaction during the thermal treatments such as the hydrolysis of non reducing sugar in acid medium at high temperature.

The total sugar content of analyzed samples ranged from $8.46 \%$ to $9.65 \%$, and these values are similar to those observed by CÁMARA \& TORIJA (1995) and HODGSON \& HODGSON (1993). Regarding the reduction of sugar content it was observed a statistical difference at a level of $5 \%$ of probability among the extraction and formulation/homogenation phases. After the thermal treatment occurred an increase equal to $32.62 \%$ of reducing 
sugars that can be explained by the possible hydrolyses of non reducing sugar in acid medium at high temperature.

In relation to ascorbic acid content there was a significant difference at a level of $5 \%$ of probability amongst the processing phases decreasing from 33.68 (raw juice) to $22.21 \mathrm{mg}$ ascorbic acid in $100 \mathrm{~mL}$ (after thermal treatment). All the samples showed lower levels of vitamin $\mathrm{C}$. The occurrence of chemical and biochemical degradation of ascorbic acid during the technological process applied (MOßHAMMER et al., 2005; BURDURLU et al., 2006; POLYDERA et al., 2005; JOHNSTON \& HALE, 2005; VIRKRAM et al., 2005) and the dilution during the formulation of the juice have been found to be major causes of this decrease.

The bottle tropical pineapple juice

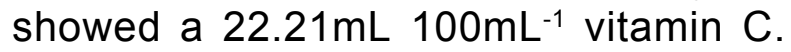
Similar results were found by MATSUURA \& ROLIM (2002) that found $20.9+1.0 \mathrm{mg}$ vitamin C content in $100 \mathrm{~g}$ of tropical pineapple juice.

The ingestion of $200 \mathrm{~mL}$ (1 portion) of juice of tropical pineapple juice after dilution $1: 5$ would supply $16.44 \%$ of the Recommended Daily Ingestion (RDI) for adults, that is $45 \mathrm{mg}$ (BRASIL, 2005).

The carotenoid content did not showed a significant statistical difference at a level of $5 \%$ of probability during the processing phases, although it was found an increase of $40 \%$ after the thermal treatment. This could be explained by the wall cell rupture becoming â-carotene bio-available.

This higher retention is due to relatively heat-stable properties of carotenoids (CHEN et al., 2004). SIAN \& ISHAK (1991) obtained a higher retention of carotenoids incommercially pineapple juice after blanching and drying processes. GARDNER et al. (2000) working on relative contributions of vitamin $C$, carotenoids and phenolics to the antioxidant potential of different kinds of fruit juices found in fresh-squeezed pineapple juice low carotenoid concentrations, and in some cases below the limits of detection.
The anthocyanins content showed a significant statistical difference at a level of $5 \%$ of probability during the processing. A decrease of $64.51 \%$ was found afterwards the thermal treatment. Temperature rise in $\mathrm{pH}$ values 2-4 induces the loss of the glycosyl moieties of the anthocyanins, by hydrolysis of the glycosidase bond (ADAMS, 1973).

According to REIN (2005) anthocyanins are highly unstable and easily susceptible to degradation. The stability of anthocyanins is affected by $\mathrm{pH}$, storage temperature, presence of enzymes, light, oxygen, structure and concentration of the anthocyanins, and the presence of other compounds such as other flavonoids, proteins, and minerals. The results of this work are in agreement with those from MIKKELSEN \& POLL (2002) that reported a loss around $30 \%$ during the black currant juice processing. KIRCA et al. (2006) observed a fast degradation of anthocyanins in pineapple nectar during storage at $37^{\circ} \mathrm{C}$, and such degradation followed a first-order reaction kinetics.

REIN (2005) found that the presence of oxygen, together with elevated temperature, was the most detrimental combination of many factors tested against color deterioration of different berry juices and isolated anthocyanins. Oxygen together with ascorbic acid was also found damaging to the anthocyanin stability of cranberry juice

Anthocyanin decomposition is accelerated by the presence of ascorbic acid (MARTI et al., 2002). Ascorbic acid enhances polymer pigment formation and bleaches anthocyanin pigments. Direct condensation between anthocyanin and ascorbic acid has been postulated as a mechanism for anthocyanin degradation (POEI-LANGSTON \& WROLSTAD, 1981). Also the formation of hydrogen peroxide from ascorbic acid oxidation can influence anthocyanin stability (TALCOTT et al., 2003). KIRCA et al. (2005gac) report the importance of time and temperature of the thermal treatment in the discoloration of pineapple juice and suggested temperature 
around $80^{\circ} \mathrm{C}$ for minimize the anthocyanins degradation.

The color parameter showed a decrease of $26.31 \%$ with a significant statistical difference at a level of $5 \%$ of probability during the processing phases. This increase in absorbance could be explained by nonenzymatic browning reactions such as the assumption that high temperature accelerated the carotenoid isomerization which led to the loss of yellowness (CHEN et al., 1995).

During processing, deterioration reactions contribute to the formation of a brown pigment that is undesirable with respect to color, flavor and market value. RATTANATHANALERK et al. (2005) presented thermal effect on the quality loss of pineapple juice at 55-95 ${ }^{\circ} \mathrm{C}$. CHUTINTRASRI \& NOOMHORMB (2006) studied the color degradation kinetics of pineapple puree during thermal processing and concluded that the color difference - "E

\section{REFERENCES}

ABACAXI: melhoramento visando resistência à fusariose. Toda Fruta (online) São Paulo, 28 de fevereiro de 2005. Disponível na Internet em: <http://www.todafruta.com.br>. Acesso em 01 de março de 2006.

ADAMS,J.B. Thermal degradation of anthocyanins with particular reference to the 3-glycosides of cyanidin. I. In acidified aqueous solution at $100{ }^{\circ} \mathrm{C}$. Journal of the Science of Food and Agriculture, London, v.24, n. 7, p.747-762, 1973.

BARTHOLOMEW, D.P.; PAUL, R.E.; ROHRBACH, K.G. (Eds.) The pineapple: botany, production and uses. New York: CABI Publishing, 2002. 400p.

BRASIL. Ministério da Saúde. Agência Nacional de Vigilância Sanitária. Métodos Físicos-Químicos para Análise de and lightness, based on activation energy, were the most sensitive measures of color change at temperature range $70-90^{\circ} \mathrm{C}$ and $95-110^{\circ} \mathrm{C}$, respectively.

\section{CONCLUSIONS}

It was verified that all the compositional and physicochemical parameters evaluated showed a statistical difference at a level of $5 \%$ of probability by the Tukey test, exception carotenoid content. Total treatable acidity, reducing sugar and carotenoid content increased during the processing. The $\mathrm{pH}$, total soluble solids (Brix), total sugars and anthocyanins content did not differed statistically among formulation/homogeneity and thermal treatment phases. The results suggested that processing phases such as extraction, formulation/homogeneity and thermal treatment had a significant effect on the compositional and physicochemical characteristics of the tropical pineapple juice.

Alimentos. Brasília: Ministério da Saúde, 2005. $1018 \mathrm{p}$.

BRASIL. Secretaria da Vigilância Sanitária/ MS. Tabelas de ingestão diária recomendada (IDR). Portaria n. 269 de 22 de setembro de 2005. Diário Oficial da União de 23 de setembro de 2005.

BURDURLU,H.S.; KOCA, N.; KARADENIZ, $F$. Degradation of vitamin $C$ in citrus juice concentrates during storage. Journal of Food Engineering, England, v.74, n.2, p.211-6, 2006.

CÁMARA, M.; DIEZ, C.; TORIJA, E. Chemical characterization of pineapple juices and nectars. Principal components analysis. Food Chemistry, London, v.54, n.1, p. 93-100, 1995. 
CHEN, H. E.;PENG, H.Y.; CHEN, B.H. Changes of carotenoids, color and vitamin A contents during processing of carrot juice. Journal of Agricultural and Food Chemistry, Washington, D.C., v. 43, n.7, p.1912-1918, 1995.

CHUTINTRASRI, B.; NOOMHORMB, A.Thermal inactivation of polyphenoloxidase in pineapple puree. LWT - Food Science and Technology, London, v.39, n.5, p.492495, 2006.

COX, H.E.; PEARSON, D. Técnicas de laboratório para el analisis de alimentos. Zaragoza: Acribia, 1976. 331p.

DANIEL, Isaura. Lugar de fruta é na indústria do suco. Agência de Notícias Brasil-ÁrabeANBA. (on-line) Brasília: ANBA, 2006. (Citado em: 08/0/2006) Disponível na Internet : < http://www.anba.com.br/ noticia. php?id=11353>.

FRANCIS, F.J. Analysis of anthocyanins. In: MARKAKIS, P (Ed.), Anthocyanins as food colors. New York: Academic Press, 1982. p.181-207.

GAHLER, S.; OTTO, K.; BÖHM, V. Alterations of vitamin $\mathrm{C}$, total phenolics, and antioxidant capacity as affected by processing tomatoes to different products. Journal of Agricultural and Food Chemistry, Easton, v.51, n.25, p.7962-68, 2003.

GARDNER,P.T.; WHITE, T.A.C.; MCPHAIL, D.B.; DUTHIE, G.G. The relative contributions of vitamin $\mathrm{C}$, carotenoids and phenolics to the antioxidant potential of fruit juices. Food Chemistry, London, v.68, n.4, p.471-474, 2000.

GIMENEZ, R.; CABRERA, C.; OLALLA, M.; RUIZ, M.D.; LOPEZ, M.C. Ascorbic acid in diet supplements: loss in the manufacturing process and storage. International Journal of Food Science and Nutrition, v.53, n.6, p.509-518, 2002.
HIGBY, W.K. A simplified method for determination of some the carotenoid distribution in natural and carotene - fortified orange juice. Journal of Food Science, Chicago, v.27, n.1, p.42-49, 1962.

HODGSON, A.S.; HODGSON, L.R. Pineapples juice. In: NAGY, S.; CHEN, C.S.; SHAW, P.E (Ed.) Fruit juice processing technology. Auburndale: AgScience, 1993.

JOHNSTON, C.S.; HALE, J.C. Oxidation of ascorbic acid in stored orange juice is associated with reduced plasma vitamin $\mathrm{C}$ concentrations and elevated lipid peroxides. Journal of the American Dietetic Association, Chicago, v.105, n.1, p.106109, 2005.

KIRCA, A.; ÖZKAN, M., O.; CEMEROGLU, B. Stability of black carrot anthocyanins in various fruit juices and nectars. Food Chemistry, London, v.97, n.4, p.598-605, 2006.

LIMA, V.L.A.G.; MÉLO, E.A.; LIMA, L.S.; NASCIMENTO, P.P. Flavonóides em seleções de acerola (Malpighia sp. L.). 1Teor de antocianinas e flavonóis totais. Ciência Rural, Santa Maria, v.30, n.6, p.1063-1064, 2001.

MAIA, G.A. Production and processing of tropical fruit juices from Brazil. In: 23 rd IFU Symposium, 2000, Havana. 23 rd. IFU Symposium. v.1. p.128-139, 2000.

MARTI, N.; PEREZ-VICENTE, A.; GARCIAVIGUERA, C. Influence of storage temperature and ascorbic acid addition on pomegranate juice. Journal of the Science of Food and Agriculture, London, v.82, n.5 p.217-221, 2002.

MATSUURA, F.C.A.U.; ROLIM, R.B. Avaliação da adição de suco de acerola em suco de abacaxi visando à produção de um "blend" com alto teor de vitamina C. Revista Brasileira de Fruticultura, Jaboticabal, v.24, n.1, p.138-141, 2002. 
MIKKELSEN, B.B.; POLL, L. Decomposition and transformation of aroma compounds and anthocyanins during black currant (Ribes nigrum L.) juice processing. Journal of Food Science, Chicago, v.67, n.9, p.3447-55, 2002.

MILLER, G.L. Use of dinitrosalicylic acid reagent for determination of reducing sugars. Analytical Chemistry, Washington, v.31, p.426-428, 1959.

MOßHAMMER, M.R.;STINTZING, F.C., CARLE, R. Development of a process for the production of a betalain-based colouring foodstuff from cactus pear. Innovative Food Science \& Emerging Technologies, v. 6, n. 2, p.221-231, 2005.

MORE juice from the tropics. Biotimes (online). Bagswaerd, Dinamarca, 01 mar. 2002. Novozymes. Disponível na Internet : <http:// www.novozymes.com/cgibin/bvisapi.dll/ biotimes/one_article.jsp?id=17650\&lang= en\&t=b1>. Acess: 01 Mar 2006.

POEI-LANGSTON, M.S.; WROLSTAD, R.E. Color degradation in an ascorbic acidanthocyanin-flavonol model system. Journal of Food Science, Chicago, v.46, n.4, p.1218-1222, 1981.

POLYDERA, A.C.; STOFOROS, N.G.; TAOUKIS, P.S. Quality degradation kinetics of pasteurized and high pressure processed fresh Navel orange juice: Nutritional parameters and shelf life. Innovative Food Science \& Emerging Technologies, v. 6, n. 1, p.1-9, 2005.

RANGANA, M. Manual of analysis of fruit and vegetable products. New Delhi: MacGraw Hill, 1997. 643p
RATTANATHANALERK, M.; CHIEWCHAN, N.; SRICHUMPOUNG, W. Effect of thermal processing on the quality loss of pineapple juice. Journal of Food Engineering, England, v.66, n.2, p.259-265, 2005.

REIN, M. Copigmentation reactions and color stability of berry anthocyanins, Helsinki, 2005. 88+34p. Thesis (Doctoral) University of Helsinki, Faculty of Agriculture and Forestry, Applied Chemistry and Microbiology

SAS Institute, Inc. SAS User's Guide: version 9.1, Cary, NC: SAS Institute, 2006. Disponível em : <http://www.sas.com/ Copyright.html>

SIAN, N.K.; ISHAK, S. Carotenoid and anthocyanin contents of papaya and pineapple: influence of blanching and predrying treatments. Food Chemistry, London, v.39, n.2, p.175-185, 1991.

TALCOTT, S.T.; BRENES, C.H.; PIRES, D.M.; DEL POZO-INSFRAN, D. Phytochemical stability and color retention of copigmented and processed muscadine grape juice. Journal of Agricultural and Food Chemistry, Easton, v.51, n.4, p.957963, 2003.

VIKRAMgac, V.B.; RAMESH, M.N.; PRAPULLA, S.G. Thermal degradation kinetics of nutrients in orange juice heated by electromagnetic and conventional methods. Journal of Food Engineering, England, v. 69, n.1, p.31-40, 2005. 